\title{
III-Turas
}

P-ISSN : 0853-1692 E-ISSN : 2579-5848

website : bit.ly/buletinalturas

\section{The Confusion of Language Creativity in Labelling Millennial Business Unit in Public Spaces}

\author{
Sahrul Romadhon \\ IAIN Madura \\ Jawa Timur, Indonesia \\ sahrul@iainmadura.ac.id
}

\begin{abstract}
The purpose of this study was to document the confusion of the written language use development in the millennial era, especially in creative economic domains of business units, such as restaurants, coffee shops, cafes, or other millennial generation businesses. The study used a phenomenological qualitative research. The data of the research were business unit labels found in the public areas to attract the consumers. All labels of millennial business units were qualitatively analyzed using syntactic techniques. The research revealed various labels of business units as products of language creativity leading to language confusion. This was a phenomenon deliberately chosen by millennial business owners to get commercial value for consumers. Based on these findings, the research concluded that the labelling of millennial business units could be categorized into several variations, namely: 1) naming millennial business units with the absorption of foreign languages, 2) spelling, and 3) meaning. Therefore, the research suggests to conduct socialization to the millennial business unit owners about the rules of language uses in public spaces so that the existence of the Indonesian language and the commercial side could go hand in hand.
\end{abstract}

Keyword: creative economy, millennial generation, language creativity 


\begin{abstract}
Abstrak
Tujuan penelitian ini adalah untuk mendokumentasikan gejala perkembangan pemakaian bahasa tulis pada era milenial, khususnya pada ranah perkembangan ekonomi kreatif nama unit-unit usaha rumah makan, warung kopi, kafe, atau usaha para generasi milenial lainnya. Metode yang digunakan dalam penelitian ini adalah metode penelitian kualitatif berjenis fenomenologis. Beragam temuan data penamaan unit-unit usaha milenial kemudian dianalisis menggunakan teknik sintaktik. Hasil penelitian menunjukkan bahwa penggunaan kreativitas bahasa tersebut pada akhirnya menimbulkan kegamangan bahasa sebagai fenomena yang sengaja dipilih oleh pemilik usaha milenial untuk mendapatkan nilai komersial bagi konsumen. Berdasarkan hasil temuan tersebut dapat disimpulkan bahwa penamaan unit-unit usaha milenial dapat dikategorikan menjadi beberapa variasi, yaitu 1) penamaan unit usaha milenial dengan kreativitas penyerapan bahasa asing, 2) ejaan, dan 3) pemaknaan. Saran yang dapat dilakukan agar eksistensi bahasa Indonesia dan sisi komersial dapat berjalanan beriringan adalah dengan mengadakan sosialisasi kepada pelaku unit usaha milenial tentang aturan perundang-undangan penggunaan bahasa di ruang publik.
\end{abstract}

Kata kunci: ekonomi kreatif, generasi milenial, kreativitas bahasa

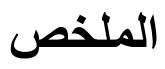

الغرض من هذه الدراسة هو توثيق أعر اض تطور استخدام اللغة المكتوبة في عصر الألفية، وخاصة في مجال تطوير الاقتصاد الإبداعي للوحدات التجارية للمطاعم أو المقاهي أو الأعمال التجارية لأجيال الأبهال

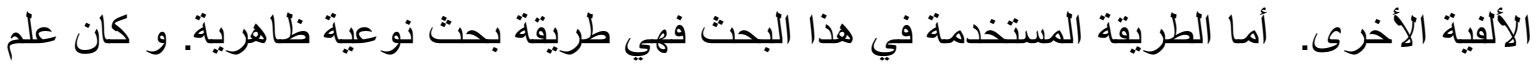

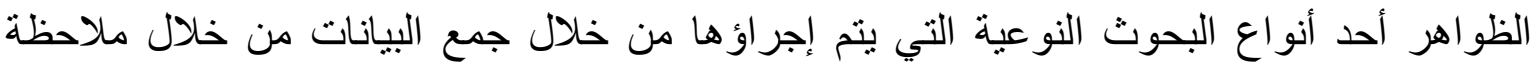
المشاركين لتحديد الظواهر الأساسية للمشارك. ثم يتم تحليل النتائج المختلفة لتسمية وحدات التهية الأعمال من خلال التقنيات النحوية. و استنادًا إلى هذه النتائج، يلاحظ الباحث أنئ أن تسمية الوحدات الألفيّة بمكن

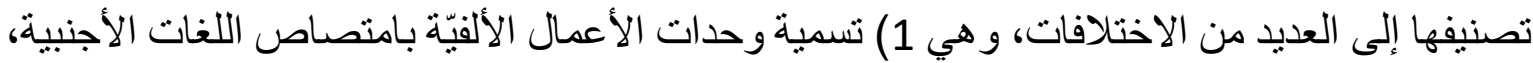
2) الهجاء، و 3) المعنى. و يؤدي استخدام إبداع اللغة في نهاية المطاف إلى إربالك اللغة كظاهرة

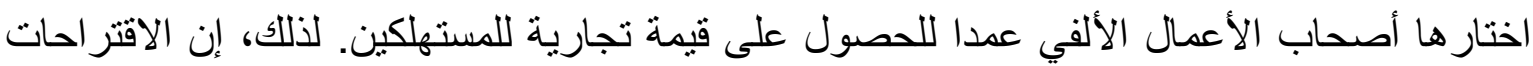
من هذا البحث إجر اء التنشئة الاجتماعية لوحدات الأعمال الألفية حول قو اعد استخدام اللغة في الأماكن العامة.

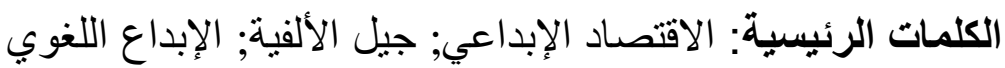




\section{PENDAHULUAN}

Hakikat ekonomi industri kreatif telah dilakukan sejak tahun 1988 yang dipelopori oleh Departement of Cultural, Media and Sports (DCMS) milik pemerintah Inggris (Muis, 2019, p.10,Firdausy, 2017). Di Indonesia, Peraturan Presiden Republik Indonesia Nomor 142 Tahun 2018 Pasal 26 (PP No.142, 2018) menyebutkan pengembangan ekosistem usaha bidang ekonomi kreatif dilaksanakan pada 15 subsektor, antara lain (a) aplikasi dan game developer, (b) arsitektur, (c) desain interior, (d) desain komunikasi visual, (e) desain produk, (f) fashion, (g) film, animasi, dan video, (h) fotografi, (i) kriya, (j) kuliner, (k) musik, (l) penerbitan, (m) periklanan, (n) seni pertunjukan, (o) seni rupa, dan (p) televisi dan radio. Melalui sektor-sektor industri tersebut, peran ilmu bahasa dibutuhkan sebagai alat yang digunakan untuk menciptakaan keadaan persuasif bagi para konsumen industri kreatif. Hal tersebut disebabkan oleh adanya rasa penasaran akan keunikan dari kreativitas penamaan unit usaha. Nurwicaksono (2016, p.15) menunjukkan keterampilan bahasa secara vokasional untuk mewujudkan ide kreatif menjadi produk kreatif. Misalnya, pada subsektor industri kreatif periklanan dan produk, keterampilan menulis konten-konten berbasis bahasa sangat diperlukan dalam menciptakan bahasa iklan yang kreatif dan persuasif sehingga memberikan kesan berbeda dengan produk lain.

Pembahasan pada artikel ini bersumber pada perkembangan penamaan unit usaha milenial yang tersebar di ruang publik. Perkembangan penamaan tersebut berjalan begitu cepat yang kemudian berbenturan dengan kaidah-kaidah kebahasaan dan peraturan perundang-undangan. Sesuai Undang-Undang Republik Indonesia (Pasal 36 Nomor 24) Tahun 2009 tentang bendera, bahasa, dan lambang negara, serta lagu kebangsaan pasal 3 disebutkan bahwa bahasa Indonesia wajib digunakan untuk nama bangunan atau gedung, jalan, apartemen atau permukiman, perkantoran, kompleks perdagangan, merek dagang, lembaga usaha, lembaga pendidikan, organisasi yang didirikan atau dimiliki oleh warga negara Indonesia atau badan hukum Indonesia.

Perkembangan penamaan unit usaha melenial di ruang publik telah berkembang dan dikonsumsi secara langsung oleh masyarakat. Artikel ini akan membahas tentang fenomena perkembangan temuan variasi bahasa bidang penamaan unit usaha generasi milenial sebagai fenomena perkembangan pada era ekonomi kreatif yang secara langsung ditemukan di ruang publik. Gillabert (2017b, p.18) menjelaskan bahwa generasi millenial juga dikenal sebagai generasi Y (merujuk pada orang yang lahir antara tahun 1981 dan 1999) yang memiliki kekhususan sebagai generasi multikultural, digital, internasional, dan skeptis. Sebagai generasi skeptis, generasi milenial merupakan generasi yang skeptis (ragu-ragu). Generasi ini cenderung memiliki rasa penasaran yang cukup tinggi terhadap hal-hal baru dan berusaha mendapatkan informasi sedetail mungkin.

Termasuk fenomena munculnya hal baru penamaan tempat usaha milenial. Beragam variasi penggunaan penamaan digunakan sebagai alat untuk menarik perhatian konsumen. Selain itu, penamaan tersebut digunakan sebagai perwakilan identitas pemilik usaha milenial. Mazor (2018, p.21) melalui sebuah penelitian dengan judul Symbolism as the Language of Millennials menyatakan bahwa semiologi telah diterapkan pada desain ikon untuk mengeksplorasi cara bahasa piktografi menggantikan bahasa tertulis untuk tujuan relevansi milenial. Artinya, sesuai kebutuhan pemasaran, fenomena semiotik telah dengan sengaja digunakan untuk menarik perhatian dan rasa penasaran milenial khususnya yang berhubungan dengan penamaan unit usaha. 
Beberapa penelitian sejenis pernah dilakukan oleh para pemerhati bahasa Indonesia khususnya yang berkaitan dengan penggunaan Bahasa Indonesia di ruang publik. Misalnya, sebuah artikel yang berjudul Geliat Aksara dan Bahasa Ganda dalam Papan Nama Jalan di Indonesia (Erikha, 2018) dari Universitas Indonesia, Pemakaian Bahasa Indonesia dalam Lanskap Linguistik di Bandara International Soekarno Hatta (Gunawan, 2018), Bahasa, Kekuasaan, dan Restitansinya: Studi Tentang Nama-Nama Badan Usaha di Daerah Istimewa Yogyakarta ( Putu, 2014).

Pada penelitian pertama, karya Erikha, menekankan tentang fenomena di ruang publik yang berkaitan dengan papan nama jalan. Penulisan papan nama jalan cenderung menggunakan Bahasa Indonesia yang di bawahnya dituliskan Bahasa Jawa, atau aksara daerah lainnya. Penelitian kedua, pembahasan oleh Gunawan (2018) lebih ditekankan pada tidak konsistennya penulisan Bahasa Indonesia dan bahasa asing di Bandara Internasional Soekarno Hatta. Hal tersebut tampak dari adanya berbagai temuan dominasi tulisan bahasa asing (diletakkan di atas) terhadap Bahasa Indonesia (diletakkan di bawah). Penelitian ketiga yang dilakukan oleh Putu (2014), lebih ditekankan pada kekushusan penggunaan badan usaha di wilayah Yogyakarta. Penggunaan bahasa daerah seringkali digunakan sebagai sebagai naluri kedaerahan atau budaya jawa, seperti Restoran Pring Sewu (Restoran Bambu Seribu), Moro Kangen (Datang Kangen), Ngudi Rejeki (Menantikan Rejeki). Nama-nama tersebut cenderung menggunakan istilah bahasa Jawa padahal pengunjung unit usaha tersebut sebagian besar berasal dari luar jawa yang tentu tidak mengerti Bahasa Jawa.

Perbedaan dari ketiga penelitian tersebut adalah tentang kreativitas bahasa. Dari sisi perkembangan daya bentuk kreativitas bahasa, peneliti pada akhirnya berusaha menunjukkan perkembangan kreativitas variasi bahasa yang dihasilkan dari penamaan unit usaha milenial di era perkembangan ekonomi kreatif. Temuan nama unik yang telah terkumpul kemudian dianalisis menggunakan kajian sistem kebahasaan bahkan ejaan lama bahasa Indonesia menyesuaikan temuan data yang dianalisis. Pembahasan ini memfokuskan kajiannya pada upaya untuk mengetahui ragam bentuk kreativitas bahasa yang digunakan sebagai penamaan unit usaha milenial.

Sehubungan dengan upaya menghasilkan temuan yang bermanfaat bagi materi kebahasaan, penelitian ini berupaya untuk (1) memerikan temuan variasi bahasa yang digunakan sebagai nama unit usaha milenial pada era ekonomi kreatif, (2) menunjukkan variasi temuan penamaan bahasa pada unit usaha milenial, dan (3) mengidentifikasi penamaan dengan bidang keilmuan bahasa.

\section{METODE}

Pada metode penelitian ini akan dipaparkan tentang a) pendekatan dan jenis penelitian, b) data dan sumber data, c) pengumpulan dan instrumen data, dan d) analisis data. Metode penelitian yang digunakan di dalam penelitian ini adalah dengan pendekatan kualitatif. Penelitian kualitatif adalah penelitian yang menghasilkan prosedur analisis yang tidak menggunakan prosedur analisis statistik atau cara kuantifikasi lainnya. Penelitian ini didasarkan pada upaya membangun pandangan yang diteliti dengan rinci, dibentuk dengan kata-kata, gambaran holistik dan rumit. Definisi ini lebih melihat perspektif emik dalam penelitian yaitu memandang sesuatu upaya membangun pandangan subjek penelitian yang rinci, dibentuk dengan kata-kata, gambaran holistik dan rumit. 
Kategori penelitian kualitatif yang dimaksud adalah fenomenologi yang dirancang dengan desain penelitian deskriptif. Fenomenologis, merupakan salah satu jenis penelitian kualitatif, di mana peneliti melakukan pengumpulan data dengan observasi partisipan untuk mengetahui fenomena esensial partisipan dalam pengalaman hidupnya. Deskripsi teori dalam suatu penelitian merupakan uraian sistematis tentang teori dan hasil-hasil penelitian yang relevan dengan variabel yang diteliti. Metode tersebut digunakan untuk mendiskripsikan fenomena penamaan unit usaha milenial. Pendekatan penelitian menggunakan analisis sintaktik (Parera, 2009).

Data penelitian ini merupakan beberapa penamaan unit usaha milenial. Sumber data penelitian ini berupa temuan variasi penamaan unit usaha milenial. Pengumpulan data dilakukan dengan beberapa tahap, 1) tahap pertama, mengumpulkan setiap data nama unit usaha milenial, 2) tahap kedua, mengidentifikasi perkembangan kreativitas penampaan unit usaha milenial, 3) menyimpulkan identifikasi data. Analisis data yang digunakan dalam penelitian ini bersumber pada konsep analisis struktural. Konsep analisis struktural dilakukan dengan menentukan satuan gramatikal yang didasarkan pada ciri bentuk dan ciri distribusinya posisi satuan lingual yang lebih kecil dalam satuan yang lebih besar, misalnya distribusi kata dalam frasa, klausa, dan kalimat).

Pada penelitian kali ini, penulis memakai pendekatan kualitatif. Setiap temuan data dianalisis berdasarkan analisis kata-kata secara holistik dan rinci. Analisis yang dimaksud berupa nama-nama unit usaha milenial yang memiliki kesan "aneh" dan berbeda dari namanama unit usaha milenial. Selain itu, sajian makanan yang dihidangkan kepada pembeli juga tidak luput dari objek penelitian. Penulis secara langsung melakukan observasi secara langsung tentang fenomena-fenomena pemberian nama di ruang-ruang publik (fenomenologi) kemudian dideskripsikan dan dihubungan dengan teori-teori kebahasaan mikro dan makro.

Berikutnya, pengumpulan data dilakukan dengan tiga tahapan. Pertama, peneliti mengumpulkan nama-nama unit usaha milenial yang berada di ruang publik. Segala macam bentuk temuan tersebut ditampung sebelum dikategorikan menjadi indikator-indikator yang akan dianalisis. Kedua, tahap identifikasi berdasarkan tiga kategori pembahasan, yaitu 1) penamaan unit usaha milenial dengan kreativitas penyerapan bahasa asing, 2) ejaan, dan 3) pemaknaan. Setelah klasifikasi tersebut dilakukan, kemudian dianalisi dan disimpulkan sesuai dengan identifikasi data.

Langkah terakhir dalam penelitian ini adalah menentukan konsep analisis struktural dilakukan dengan menentukan satuan gramatikal yang didasarkan pada ciri bentuk dan ciri distribusinya posisi satuan lingual yang lebih kecil dalam satuan yang lebih besar, misalnya distribusi kata dalam frasa, klausa, dan kalimat). Setiap temuan yang dianalis menurut frasa, klausa, dan kalimat sehingga dan dihubungkan dengan klasifikasi kreativitas bahasa asing, ejaan, dan pemaknaan.

\section{HASIL DAN PEMBAHASAN}

Setelah peneliti melakukan studi lapangan, beberapa temuan data penamaan unit usaha milenial dapat dikategorikan sebagai berikut 1) penamaan unit usaha milenial dengan kreativitas penyerapan bahasa asing, 2) penamaan unit usaha milenial menggunakan kreativitas ejaan, 3) penamaan unit usaha milenial menggunakan kreativitas pemaknaan frasa, kata, atau kalimat. Ketiga kategori temuan-temuan tersebut adalah sebagai berikut (Lampiran 1). 
Sahrul Romadhon,

The Confusion of Language Creativity in Labelling Millennial Business Unit

Temuan pertama, kategori penggunaan kreativitas bahasa berupa penyerapan bahasa asing, yaitu (1) sampai dengan (25) sebagai berikut: (1). Al Café; (2). Elizabet:Bag to School; (3). Mark Us; (4). Go Kill Café; (5). K-One Café; (6). Warkop CaffeIN; (7). Mie CJDW; (8). Mukerenz Coffe dan Resto; (9). Café OTW; (10). I'm Banana; (11). D' Lucky Café; (12). N'dra with LB; (13). Bi Queen; (14). K-Days coffe; (15). PEWE Coffe \& Dining; (16). M2 Warkop; (17). Warkop CaffeIN; (18). MANK'S Café; (19). Hedon Milkshake N Thai Tea; (20). Kedai Nun; (21). TsunaMie Noodle \& Café; (22). Shae Cafe and Eatery; (23). d'riAll Café; (24). W'ant Café; (25). CO\&B Café.

Temuan kedua, berupa kategori penggunaan kreativitas ejaan bahasa, yaitu (26) sampai dengan (36) sebagai berikut: (26). Warunk Mienie; (27). Waroeng Cak Mamat; (28). Daoen Bamboe Resto \& Café; (29). Andayani Waroeng Steak'n Djawa; (30). Djagongan Café; (31). Loe Mien Toe; (32). d' Toengkoe Cafe \& Resto; (33). Toeman Cafe and Eatery; (34). Djoedjoegan; (35). Warunk Upnormal Braga; (36). Tjarani Cafe Bandung.

Temuan ketiga, berupa kategori penggunaan kreativitas pemaknaan bahasa, yaitu (37) sampai dengan (50) sebagai berikut: (37). Bakso Beranak Mas Dodo; (38). Bakso Gong; (39). Mie Setan Kekkekek; (40). Es Kuntilanak; (41). Es Tuyul; (42). Es Sundel Bolong; (43). Bakso Rudal; (44). Mie Iblis; (45). Es Genderuwo; (46). Udang Rambutan; (47). Ceker Setan; (48). Es Pocong; (49). Bakso Klenger; (50). Bakso Beranak.

Beberapa temuan data penamaan unit usaha milenial tersebut dianalisis sehingga dapat diketahui bentuk-bentuk kreativitas bahasa berdasarkan kategori 1) penamaan unit usaha milenial dengan kreativitas penyerapan bahasa asing, 2) penamaan unit usaha milenial menggunakan kreativitas ejaan, 3) penamaan unit usaha milenial menggunakan kreativitas pemaknaan. Ketiga kategori temuan-temuan tersebut akan dijelaskan sebagai berikut.

\section{Analisis Konteks Penamaan Kreativitas Penyerapan Bahasa Asing}

Penamaan usaha milenial dengan menggunakan penyerapan bahasa asing memiliki keunikan untuk menarik perhatian konsumen. Akan tetapi, penyerapan bahasa asing ke dalam bahasa Indonesia ternyata tidak sesuai dengan tata aturan Pedoman Umum Pembentukan Istilah (2016). Kata yang diserap hanya sekadar memiliki kesamaan bunyi (fonetik) dengan bahasa lisan tanpa memperhatikan bahasa tulis baku. Pembahasan nama-nama unik ini adalah sebagain sampel yang diambil setelah sebelumnya dibahas pada temuan. Bentuk-bentuk temuan tersebut dapat diketahui melalui analisis penamaan unit-unit usaha milenial sebagai berikut: (1). I'am Geprek; (2). Al-Café; (3). Mark Us; (4). Elizabet:Bag to School; (5). Otw Café; (6). Go Kill Café; (7). K-One Café. Berikut analisis dari ketujuh nama-nama unit usaha milenial tersebut.

Nama usaha milenial yang pertama (1) I'am Geprek adalah contoh penggunaan kombinasi bahasa asing yang dipadukan dengan bahasa Indonesia. Namun, sebenarnya secara fonetik bahasa asing I'am dibaca menggunakan bahasa Indonesia. I'am dalam bahasa Inggris berarti [saya], pemilik kedai menggunakan kreativitasnya dengan harapan dapat dibaca menggunakan ejaan bahasa Indonesia yaitu [ayam] yang berarti binatang unggas yang berkokok sehingga I'am Geprek dibaca [ayam geprek] yang berarti penyebutan nama makanan khas Indonesia.

Berikutnya, penamaan usaha milenial yang kedua, yaitu (2) Al-Cafe. Seperti pada contoh pertama, contoh penamaan usaha milenial yang kedua ini menggunakan kombinasi dua bahasa yaitu bahasa arab dan bahasa inggris. Al merupakan alat grammar dalam bahasa Arab yang digunakan untuk menyokong sebuah makna. Dalam bahasa Indonesia $A l$ bermakna nya atau pronomina. Penggunaan kreativitas penamaan Al Cafe memang memiliki bunyi dan seolaholah bermakna arab dengan tujuan untuk menarik perhatian pelanggan. Namun, apabila 
diterjemahkan secara literal menjadi bermakna [kafenya]. Suatu makna dari sebuah nama yang tidak memiliki kejelasan dalam bahasa Indonesia.

Selanjutnya, pada contoh ketiga, nama usaha milenial (3) Mark Us berasal dari bahasa inggris yang apabila diartikan bermakna [tandai kami]. Akan tetapi, secara harfiah Si Pemilik usaha tidak menginginkan setiap orang membaca dan mengartikan secara langsung menggunakan bahasa inggris. Pemilik usaha mengharapkan bahasa tulis mark us dibaca atau berfonetik [mak nyus] yang merupakan ungkapan atau ekspresi sebuah kelezatan cita rasa sebuah sajian hidangan makanan.

Penamaan usaha milenial yang keempat, yaitu (4) Elizabet: Bag to School. Penamaan ini menjadi temuan berikutnya yang memiliki kadar khusus untuk diteliti. Apabila dianalisis, [Bag] dalam bahasa Inggris berarti tas. Namun, pemilik usaha tidak serta merta menggunakan kata [Bag] yang merupakan bagian dari slogan di salah satu toko itu sebagai makna harfiah atau sebenarnya. Pemilik usaha mencoba memberikan kreativitas bahasa tulisan tersebut agar dibaca [back] yang berarti kembali (dalam hal ini kembali ke sekolah). Penggunaan [bag] difungsikan oleh pemilik usaha milenial sebagai daya tarik tersendiri karena pemilik usaha tersebut bergerak dalam bidang jual beli tas.

Analisis nama usaha milenial selanjutnya adalah 5) Otw Cafe. Apabila dianalisis, [Otw] merupakan akronim dari bahasa Inggris yang berarti On The Way. Namun, Otw Cafe tidak berarti sebuah cafe yang sedang dalam perjalanan atau pada tahap sebuah usaha yang sedang proses berkembang. Pemilik usaha berasumsi, pemilihan nama ini memiliki daya tarik tersendiri dari pelanggan karena istilah berbahasa Inggris [Otw] sangat familiar digunakan oleh para penutur Indonesia sehingga mudah diingat dan diucapkan.

Temuan lain penamaan unit usaha milenial yang keenam yakni (6) Go Kill Café. Go Kill Café apabila diterjemahkan nama tersebut memiliki arti [pergi bunuh kafe]. Namun, pemilik usaha melenial tersebut berharap konsumen tidak mengartikan secara langsung makna Go Kill Café melainkan nama tersebut diartikan sesuai penamaan bahasa Indonesia [Gokil] yang berarti [Gil(a)]. Kata ini berasal dari dialek (dialek adalah bahasa sekolompok masyarakat yang tinggal di daerah tertentu (Sumarsono (2012, p.21); Chaer, A. (2011, p.63) khas bahasa Jakarta setelah ditambahkan ok di tengah. Sama seperti [Bokap] (Bapak ditambah ok, [Nyokap](Nyak/Ibu disisipkan ok). Gila berarti memiliki makna [tidak biasa]. Pemilik kafe memiliki asumsi yang kemudian berharap dapat diartikan oleh konsumen [Go Kill Café] bukan seperti arti bahasa Inggris melainkan [Gokil] yang berarti [Gila] dalam bahasa Indonesia atau menjadi Kafe yang tidak biasa dibandingkan dengan kafe-kafe lainnya.

Terakhir, analisis penamaan yang menggunakan konteks penamaan kreativitas penyerapan bahasa asing selanjutnya, yaitu (7) K-One Café. Nama tempat usaha milenial (7) K-One Café. Merupakan sebuah nama yang secara tertulis menggunakan bahasa Inggris. Akan tetapi, pemilik usaha milenial tersebut berharap konsumen tidak mengartikan bahasa Inggris sebagai tujuan. Pemilik usaha menginginkan agar konsumen membaca (7) K-One Café menggunakan ejaan bahasa Indonesia yaitu [kawan kafe]. [Kawan] berasal dari bacaan lidah Indonesia [K-One] sehingga [kawan] kafe berarti orang (kafe) yang sudah lama dikenal oleh konsumen atau dapat juga diartikan sebagai sahabat kafe para konsumen.

Fenomena-fenomena ini termasuk ke dalam kreativitas bahasa menurut Jones (2015 p.41) yang menjelaskan bahwa seseorang dapat memiliki dua cara untuk memproduksi bahasa secara kreatif, pertama gagasan kreativitas bahasa dapat dikaitkan dengan pola linguistik asli atau struktur linguistik yang baru. Dengan demikian, kata-kata yang dihasilkan cenderung berpola linguistik yang teratur (tetapi baru), seperti kata, kalimat, atau teks baru, dapat dianggap 
Sahrul Romadhon,

The Confusion of Language Creativity in Labelling Millennial Business Unit

mencerminkan kreativitas berbasis bahasa. Misalnya dalam Bahasa Indonesia baku terdapat daring dan luring. Kedua, kreativitas linguistik juga dapat dikaitkan dengan produk komunikatif yang lebih tidak konvensional diproduksi secara kreatif melalui bahasa, seperti melibatkan bahasa kiasan (metafora, metonimi), genre sastra, permainan kata-kata, dan humor verbal (ironi dan sarkasme).

Jenis temuan analisis konteks penamaan kreativitas penyerapan bahasa asing tersebut di atas termasuk jenis kreativitas yang kedua yaitu lebih tidak konvensional, menggunakan permainan kata-kata. Selain itu, terdapat nilai humor verbal untuk menarik perhatian konsumen.

Perbedaan dengan penelitian sebelumnya yang berjudul Bahasa, Kekuasaan, dan Restitansinya: Studi Tentang Nama-Nama Badan Usaha di Daerah Istimewa Yogyakarta (Putu, 2014) adalah perkembangan kreativitas bahasa yang terbukti dengan permainan kata atau ejaan bahasa asing namun diucapkan dalam bahasa Indonesia dengan harapan makna atau arti dari nama-nama tersebut menggunakan arti bahasa Indonesia. Berbeda dengan peneltian Putu (2014) yang menginformasikan pemakaian bahasa asing dalam nama-nama badan usaha di Yogyakarta tanpa menganalisis kreativitas bahasa.

\section{Analisis Konteks Penamaan Kreativitas Ejaan}

Penamaan usaha milenial dengan menggunakan konteks kreativitas ejaan cenderung menggunakan ejaan lama Van Ophuijsen tahun 1901. Ejaan tersebut memiliki tata aturan berbeda dibandingkan PUEBI (Pedoman Umum Ejaan Bahasa Indonesia) yang digunakan menarik perhatian konsumen. Ciri khas yang dimaksud adalah (a). penulisan huruf ' $j$ ' untuk menuliskan bunyi ' $y$ '; (b). penulisan huruf 'oe' untuk menuliskan bunyi ' $u$ '; (c). penulisan huruf 'tj' untuk menuliskan bunyi 'c'; (d). penulisan huruf 'dj' untuk menuliskan bunyi 'j'. Bentukbentuk temuan tersebut dapat diketahui melalui analisis penamaan unit-unit usaha milenial berikut: (1). Warunk Mienie; (2). Waroeng Cak Mamat; (3). Daoen Bamboe Resto \& Café; (4). Andayani Waroeng Steak'n DjawA; (5) Djagongan Cafe, (6) TsunaMie Noodle \&Café, (7) Djoedjoegan.

Nama (1) Warunk Mienie merupakan suatu contoh bentuk kreativitas ejaan yang memadukan unsur bunyi untuk mendapatkan efek zaman dahulu suatu ejaan. Apabila dibaca secara harfiah, nama unit usaha tersebut berbunyi [warun] [mienie]. Namun, bacaan secara harfiah tersebut tidak berlaku, Si pemilik usaha milenial berharap setiap pengunjung membaca ejaan tersebut [warung] [mini]. Selain itu ada efek ejaan [mie] yang menjadi daya tarik dan identitas usaha milenial tersebut sebagai tempat yang menjual mie-mie.

Apabila dianalisis secara ejaan, penamaan usaha (2) Waroeng Cak Mamat tersebut menyalahi aturan Pedoman Umum Ejaan Bahasa Indonesia (PUEBI). Bahkan, ejaan yang digunakan menggunakan ejaan Van Ophuijsen tahun 1901 (Sudaryanto, 2018, pp.58-67). Hal tersebut tampak dari penulisan gabungan huruf vokal oe pada kata Waroeng. Pemilik kedai berharap setiap pembaca atau pelanggan tidak membaca secara harfiah $[o e]$ melainkan $[\mathrm{u}]$. Fenomena tersebut sesuai dengan tata aturan ejaan lama Van Ophuijsen tahun 1901, yaitu penulisan huruf 'oe' untuk menuliskan bunyi ' $u$ '.

Penamaan usaha (3) Daoen Bamboe Resto \& Café sama dengan contoh pemanamaan usaha milenial yang kedua. Apabila dianalisis secara ejaan, nama unit usaha milenial tersebut menyalahi aturan Pedoman Umum Ejaan Bahasa Indonesia (PUEBI). Bahkan, ejaan yang digunakan menggunakan ejaan Van Ophuijsen tahun 1901 (Sudaryanto, 2018). Hal tersebut tampak dari penulisan gabungan huruf vokal oe pada kata Daoen dan Bamboe. Pemilik kedai berharap setiap pembaca atau pelanggan tidak membaca secara harfiah $[o e]$ melainkan $[\mathrm{u}]$ 
sehingga ejaan tersebut dibaca [daun] dan [bambu]. Fenomena tersebut sesuai dengan tata aturan ejaan lama Van Ophuijsen tahun 1901, yaitu penulisan huruf 'oe' untuk menuliskan bunyi 'u'.

Jika dianalisis secara ejaan, penamaan usaha (4) Andayani Waroeng Steak'n Djawa tersebut menyalahi aturan Pedoman Umum Ejaan Bahasa Indonesia (PUEBI). Bahkan, ejaan yang digunakan menggunakan ejaan Van Ophuijsen tahun 1901 (Sudaryanto, 2018). Hal tersebut tampak dari penulisan gabungan huruf vokal oe pada kata Waroeng dan Djawa. Pemilik kedai berharap setiap pembaca atau pelanggan tidak membaca secara harfiah [oe] melainkan [u] dan tidak membaca secara harfiah [dj] melainkan [j]. Oleh karena itu, ejaan tersebut dibaca [warung] dan [jawa]. Fenomena tersebut sesuai dengan tata aturan ejaan lama Van Ophuijsen tahun 1901, yaitu penulisan gabungan huruf ['oe'] untuk menuliskan bunyi ['u'] dan gabungan huruf ['dj'] untuk [j].

Temuan penamaan unit usaha milenial yang kelima (5) Djagongan Cafe merupakan bentuk perwujudan kreativitas ejaan yang menggunakan ejaan Van Ophuijsen yaitu [dj]. Hal tersebut tentu bertentangan dengan Pedoman Umum Ejaan Yang Disempurnakan (PUEBI) sebagai ejaan resmi yang berlaku di Indonesia. Dalam PUEBI penulisan abjad terbaru [dj] sudah tidak berlaku karena setiap penulis dapat menulis secara langsung huruf abjad [j].

Bentuk lain kreativitas ejaan, juga terdapat pada penamaan sebuah tempat rumah makan bernama (6) TsunaMie Noodle \& Café. Ejaan yang digunakan berasal dari gabungan kata Bahasa Indonesia dan Bahasa Inggris. Apabila dianalisis, khususnya penamaan Tsunamie, ejaan ini sebenarnya tidak berdasar pada aturan ejaan manapun (Van Ophuijsen, Suwandi, atau PUEBI). Pemilik usaha berusaha memberikan kesan berbeda dengan nama-nama unit usaha lainnya yaitu adanya persamaan bunyi meskipun secara makna dan redaksional tulisan berbeda.

Selanjutnya, penamaan unit usaha yang ketujuh (7) Djoedjoegan. Penamaan unit usaha ini menggunakan ejaan lama (Van Ophuijsen dan Suwandi). Hal itu dapat diketahui dari tampilan teks tertulis [dj] dan [oe] pada nama Djoedjoegan [berharap dibaca Jujukan (diambil dari bahasa jawa) yang dalam bahasa Indonesia berarti [tempat tujuan]. Kedua, ejaan teks tertulis [dj] dan [oe] tersebut termasuk ejaan lama yang dari segi pemakaian sudah tidak lagi sesuai dengan aturan PUEBI karena aturan terbaru abjad [dj] sudah langsung dapat digantikan dengan [j] dan abjad [oe] sudah langsung dapat digantikan [u]. Beberapa kesalahan penulisan tersebut sengaja dilakukan oleh pemilik unit usaha untuk memberikan kesan kembali pada tempo dahulu tetapi secara tertulis telah melanggar tata bahasa Indonesia.

Sesuai dengan beberapa contoh, yaitu (1) Warunk Mienie; (2) Waroeng Cak Mamat; (3) Daoen Bamboe Resto \& Café; (4) Andayani Waroeng Steak’n Djawa; (5) Djagongan Café; (6) TsunaMie Noodle \&Café; dan (7) Djoedjoegan dapat disimpulkan bahwa kreativitas penamaan unit usaha milenial yang kedua teridentifikasi dari aspek analisis konteks kreativitas ejaan. Sebagian besar pola yang digunakan menggunakan ejaan Van Ophuijsen yang cenderung memakai tata aturan penulisan gabungan huruf, seperti ['oe'] untuk menuliskan bunyi ['u'] dan gabungan huruf ['dj'] untuk [j]. Fenomena ide bisnis ini cukup unik dan menjadi daya tarik setiap konsumen untuk berkunjung ke tempat unit usaha milenial karena adanya perbedaan penulisan ejaan yang berlaku (PUEBI, 2016) serta menjadi indikator perwujudan produk ekonomi kreatif. Ekonomi kreatif menurut Howkins yang dikutip oleh Suciu (2008) adalah ide bisnis, ekonomi kreatif meminta untuk mengubah ide atau gagasan menjadi produk. Kreativitas bahasa dari sisi ejaan merupakan produk dari ide atau gagasan kemudian berkembang sebagai sebagai alat komersial pada era ekonomi kreatif. 
Sahrul Romadhon,

The Confusion of Language Creativity in Labelling Millennial Business Unit

\section{Analisis Konteks Kreativitas Penamaan Makna}

Makna kata merupakan bagian dari pengetahuan tentang kata. Perhatikan kata mercon. Mercon menurut KKBI, adalah peledak yang dikemas dalam kertas dan sebagainya, biasanya bersumbu dan digunakan untuk memeriahkan berbagai peristiwa. Namun, apabila kata mercon tersebut digabungkan dengan bakso sehingga menjadi bakso mercon, tentu akan memiliki makna yang berbeda dengan makna aslinya. Bakso mercon bukan merupakan bakso yang berbahan mercon yang dapat dikonsumsi oleh konsumen, melainkan bermakna bahwa ketika konsumen memakan bakso mercon sensasi dari pedasnya seolah-olah meledak-meladak di mulut karena ciri khas utama bakso tersebut yang begitu pedas.

Penamaan usaha milenial dengan menggunakan kreativitas pemaknaan memilki keunikan untuk menarik perhatian konsumen. Hal ini sesuai dengan ciri utama bahasa yang memiliki struktur ganda yang dinamakan struktur batin (deep structure) dan struktur lahir (surface structure) sebagaimana yang dikatakan oleh Soejono (Soenjono, 2018). Dalam banyak hal struktur ini memang menyatu sehingga tidak tampak adanya perbedaan. Keunikan penamaan fenomena tersebut keberadaannya semakin menjamur di ruang publik. Bentuk-bentuk temuan tersebut dapat diketahui melalui analisis penamaan unit-unit usaha milenial berikut: (1) Bakso Beranak Mas Dodo; (2) Bakso Gong; (3) Mie Setan; (4) PEWE Coffe \& Dining; dan (5) Warunk Upnormal Braga; (6). d'riAll Café; dan (7). Kedai Laperpool.

(1) Bakso Beranak Masdodo merupakan suatu contoh bentuk kreativitas penamaan usaha melenial dari aspek makna. Seperti diketahui, ciri utama bahasa memiliki struktur ganda yang dinamakan struktur batin dan struktur lahir (Soenjono, 2018). Makna yang coba disampaikan oleh pemilik usaha adalah jenis makna struktur batin bukan struktur lahir. Pemilik usaha menamakan Bakso Beranak Mas Dodo bukan seperti makna surface strukture yang berarti bakso dapat beranak/berketurunan. Melainkan, pemilik usaha milenial berharap bahwa setiap pengunjung atau pembaca menanggap makna bahwa di dalam bakso tersebut terdiri atas beragam isi (bakso-bakso berukuran kecil) yang dapat dinikmati oleh konsumen.

Selain penamaan (1) Bakso Beranak Masdodo penamaan yang kedua (2) Bakso Gong merupakan suatu contoh bentuk kreativitas penamaan makna. Seperti diketahui, ciri utama bahasa memiliki struktur ganda yang dinamakan struktur batin dan struktur lahir (Soenjono, 2018). Makna yang ingin disampaikan oleh pemilik usaha adalah jenis makna struktur batin bukan struktur lahir. Pemilik usaha menamakan Bakso Gong bukan seperti makna struktur lahir yang berarti bakso yang besarnya selayaknya gong yang besar. Melainkan, pemilik usaha milenial berharap bahwa setiap pengunjung atau pembaca menangkap makna secara struktur batin bahwa simbol semantis yang mewakili ukuran bakso yang disajikan lebih besar dibandingkan dengan ukuran bakso pada umumnya.

Berikutnya, (3) Mie Setan merupakan suatu contoh bentuk kreativitas penamaan makna. Seperti diketahui, ciri utama bahasa memiliki struktur ganda yang dinamakan struktur batin dan struktur lahir (Soenjono, 2018). Makna yang coba disampaikan oleh pemilik usaha adalah jenis makna struktur batin bukan struktur lahir. Pemilik usaha menamakan Mie Setan bukan seperti makna makna batin yang berarti mie yang dikonsumsi setan atau mie berbentuk roh jahat. Melainkan, pemilik usaha milenial berharap bahwa setiap pengunjung atau pembaca menanggap makna struktur lahir bahwa di dalam nama tersebut mewakili pedasnya Mie yang dapat dinikmati konsumen.

(4) $\boldsymbol{P E W E}$ Coffe \& Dining termasuk jenis penamaan unit usaha milenial yang berusaha menawarkan konteks makna sebuah tempat (kafe) dengan penuh kenyamanan. Pemilik kafe sengaja menuliskan nama PEWE, yaitu sebuah singkatan yang memiliki kepanjangan [posisi 
wenak]. Kata PEWE sendiri termasuk ke dalam kosakata yang biasa digunakan oleh "anak gaul" selain Mager (Males Gerak) atau Gabut (Galau Buta). Kata PEWE (posisi wenak) juga diberikan kesan dekat dengan kaum milenial meskipun kata [wenak] berasal dari bahasa Jawa. Zulaeha, I. (2010, p.7.) menyebutkan bahwa Bahasa Jawa merupakan salah satu bahasa di Indonesia yang jumlah pemakaiannya cukup besar, yaitu sekitar 50\% dari seluruh penduduk di Indonesia. Bahasa ini digunakan sebagai bahasa ibu oleh suku Jawa. Hal ini menunjukkan bahwa memang penyebaran bahasa jawa telah sampai ruang lingkup nasional yang tentu juga dapat dikonsumsi oleh kalangan milenial termasuk dalam hal pembuatan nama sebuah unit usaha.

(5) Warunk Upnormal Braga termasuk dalam kategori contoh penamaan unit usaha milenial yang memiliki kreativitas konteks makna meskipun menggunakan bahasa asing. Dari sebuah nama yang ditampilkan oleh pemilik usaha milenial, khususnya kosakata upnormal, pemilik usaha secara tersurat menggaransi bahwa warung yang dimiliki memiliki kelebihan dari makna-makna pada umumnya. Pemilik usaha sengaja memberikan kata berbahasa asing upnormal yang berarti lebih dari normal atau di atas dibandingan dengan warung-warung lainnya. Ketidaknormalan tersebut, mungkin dapat diketahui dari, cita rasa, menu makanan, atau pelayanan prima dari warung.

Bentuk variasi penamaan unit usaha milenial lain, yaitu (6). d'riAll Café. Sepintas memang nama ini cenderung hanya dapat dianalisis dari kata serapan bahasa Inggris. Akan tetapi apabila dikaji lebih mendalam, khususnya yang berkaitan dengan kata d'riAll, akan menjadi sebuah pemaknaan yang diharapkan menjadi identitas dari pemilik kafe. D'riAll termasuk contoh nama yang menyuratakan tentang "sebuah kafe yang sebenarnya atau sesungguhnya". Maksudnya, setiap pengunjung yang berkenan untuk berkunjung tentu akan mendapatkan fasilitas yang optimal dibandingan dengan kafe-kafe yang lain. Selain,itu kata D'riAll mengisyaratkan tentang sebuah kafe dengan standar mutu tertinggi bagi para pengunjungnya.

Analisis pemaknaan nama dari sebuah usaha milenial selanjutnya tersemat dari nama (7) Kedai Laperpool. Berdasarkan nama tersebut (laperpool) dapat dianlisis bahwa ada dua suku kata yang dijadikan satu menjadi gabungan kata bermakna sebuah tim sepakbola [Liverpol]. Namun, bukan demikian yang diaharapkan oleh pemilik kedai karena bentuk tulisan yang dicantumkan tidak mewakili nama klub sepakbola melainkan terdiri dari dua suku kata [laper] dan [pool]. [Laper] atau [lapar] dalam bahasa Indonesia berarti suatu keadaan ingin makan; sedangkan [pool] atau [penuh] atau ungkapan [sangat ingin] dalam bahasa Indonesia yang berarti di kedai tersebut adalah tempat bagi konsumen yang lapar dan ingin segera makan.

Merujuk dari penjelasan detail temuan penamaan unit-unit usaha milenial, seperti (1) Bakso Beranak Mas Dodo; (2) Bakso Gong; (3) Mie Setan; (4). PEWE Coffe \& Dining; (5). Warunk Upnormal Braga; (6). d'riAll Café; dan (7). Kedai Laperpool dapat disadur sebuah temuan penelitian yaitu adanya kreativitas bahasa yang ketiga, yaitu aspek konteks pemaknaan bahasa. Dimensi kontekstual yakni penggunaannya menggunakan konteks sosiohistoris dan interpersonal sebagaimana yang dikatakan oleh Maybin \& Swann (2007, p.p 497-498).

Berdasarkan temuan tersebut, dapat diketahui bahwa selain aspek kreativitas yang berasal dari serapan bahasa asing dan kreativitas kolaborasi ejaan, pemilik usaha milenial juga memberikan kreativitas konteks pemaknaan ketika memberikan nama unit usaha yang digelutinya. Nama dan deskripsi yang tepat dapat digunakan dalam komunikasi karena entitas pemilik nama dapat diperjuangkan dan diakses oleh subjek apa pun (Popescu, 2013, p.185). Upaya tersebut diharapkan dapat mewakili produk yang dapat dikonsumsi oleh para konsumen. Sebuah perencanaan bahasa yang menjadi landasan berpikir bagi pemilik usaha. 
Hal ini sesuai dengan pendapat Moeliono (1981, p.p. 5-12) yang mendefinisikan perencanaan bahasa menjadi tiga kategori utama, yaitu perencanaan fungsional, perencanaan sebagai proses, dan penamaan yang bervariasi. Pertama, perencanaan fungsional lebih dititik beratkan pada usaha membimbing perkembangan bahasa ke arah yang diinginkan oleh para perencana. Kedua, perencanaan sebagai proses terbagi atas dua pengertian menurut Haugen dan Firshman di dalam Moeliono (1981, p.p 8-11). Haugen membagi proses perencanaan bahasa menyangkut bentuk bahasa yakni pemilihan norma bahasa yang diimplementasikan dalam kodifikasi norma yakni pernyataan eksplisit (secara tertulis) tentang norma itu. Ketiga, penamaaan yang bervariasi istilah perencanaan bahasa yang timbul pada tahun 1959, kegiatan serupa sebenarnya sudah agak lama dilakukan di berbagai kawasan.

\section{KESIMPULAN}

Fenomena perkembangan bahasa secara bebas di lingkungan masyarakat memunculkan banyak sekali kreativitas bahasa. Setiap masyarakat dapat menyampaikan bahasa-bahasa unik yang dipadukan dengan bahasa asing dan bahasa daerah (interferensi). Pada akhirnya memunculkan bahasa-bahasa baru yang menjadi konsumsi bahasa oleh masyarakat. Perkembangan ekonomi kreatif khususnya yang berhubungan dengan penamaan unit-unit usaha milenial ternyata memiliki beragam bentuk fenomena ketidaktaatan produksi bahasa. Ketidaktaatan tersebut dapat ditemukan dari beragamnya penamaan unit usaha milenial yang tersebar di ruang publik dan menjadi konsumsi publik setiap hari. Beberapa temuan fenomena ketidaktaan penamaan bahasa, antara lain (1) penamaan unit usaha milenial menggunakan kegaduhan istilah serapan dari bahasa asing, (2) penamaan unit usaha milenial menggunakan kegaduhan ejaan yang tidak resmi, dan (3) penamaan unit usaha milenial yang menggunakan kegaduhan pemaknaan. Ketika fenomena yang menjadi kegamangan tersendiri dalam pengawasan eksistensi bahasa Indonesia. Hal tersebut dikarenakan setiap kegaduhan sengaja diciptakan oleh pemilik usaha milenial untuk menarik perhatian konsumen yang sebagian besar merupakan kaum milenial. Selain itu, kegaduhan-kegaduhan tersebut sengaja diciptakan untuk meningkatkan daya saing komersial antarsetiap pemilik usaha.

Berdasarkan fenomena ragam bentuk kegaduhan penamaan unit-unit usaha milenial, saran yang dapat dilakukan agar eksistensi bahasa Indonesia dan sisi komersial dapat berjalanan beriringan adalah dengan (a) mengadakan sosialisai kepada pelaku unit usaha milenial tentang aturan perundang-undangan penggunaan bahasa di ruang publik, (b) melakukan pelayanan bimbingan teknis terkait tata cara penyerapan bahasa melalui Pedoman Umum Pembentukan Istilah (PUEBI), (c) memberikan pemahaman kepada pemilik usaha melalui sebuah ketiatan gelar wicara bahwa citarasa dan dimensi metode promosi lebih utama dibandingkan dengan pengolahan ragam bentuk penamaan yang tidak sesuai dengan ruang lingkup tata bahasa Indonesia yang baku.

\section{REFERENSI}

Chaer, A. (2011). Tata Bahasa Praktis Bahasa Indonesia. Rineka Cipta.

Erikha, F. (2018). Geliat Aksara dan Bahasa Ganda dalam Papan Nama Jalan di Indonesia. Badan Pengembangan dan Pembinaan Bahasa Kementerian Pendidikan dan Kebudayaan, 86. 
Firdausy, C.M. (2017). Strategi Pengembangan Ekonomi Kreatif di Indonesia. Yayasan Pustaka Obor Indonesia.

Gillabert, S. (2017b). Learning and Improving Languages for the Millennial Generation. Bachelor Project submitted for the obtention of the Bachelor of Science HES in International Business Management.

Gunawan, W. (2018). Pemakaian Bahasa Indonesia dalam Lanskap Linguistik di Bandara International Soekarno Hatta. Badan Pengembangan dan Pembinaan Bahasa Kementerian Pendidikan dan Kebudayaan, 71.

Indonesia, \& Badan Pengembangan dan Pembinaan Bahasa. (2016). Pedoman umum ejaan bahasa Indonesia.

Maybin, J., \& Swann, J. (2007). Everyday Creativity in Language: Textuality, Contextuality, and Critique. Applied Linguistics, 28(4), 497-517. https://doi.org/10.1093/ applin/amm036

Mazor, E. L. (t.t.). Symbolism as the Language of Millennials. 29.

Moeliono, A, M. (1981). Pengembangan dan Pembinaan Bahasa: Ancangan Alternatif di dalam Perencanaan Bahasa. Djambatan.

Muis, A.R.C. (2019). Sustainable Competitive Advantage: Ekonomi Kreatif Indonesia dalam Dinamika Perdagangan Internasional. Deepublish.

Nurwicaksono, dkk. (2016). Bahasa Indonesia Vokatif untuk Industri Kreatif. Polimedia Publising.

Parera, J. D. (2009). Dasar-dasar analisis sintaksis. Jakarta: Erlangga.

Peraturan Presiden Republik Indonesia Nomor 142 Tahun 2018 Pasal 26.

Popescu, Ş. (2013). The Description Theory of Names. 234.

Putu, W.I D. (2014). Bahasa, Kekuasaan, dan Resistansinya: Studi Tentang Nama-Nama Badan Usaha di Daerah Istimewa Yogyakarta. Humaniora, Universitas Gadjah Mada, 26, 5664.

Rodney H. Jones. (2015). Language, Creativity, and Cognition. Routledge.

Soenjono, D. (2018). Psikolinguistik: Pengantar Pemahaman Bahasa Manusia. Yayasan Pustaka Obor Indonesia.

Suciu, M.C. (2008). The Creativity Economy. Academy of Econimy Studies.

Sudaryanto, H. (2018). Pemakaian Ejaan dalam Bahasa Indonesia/Melayu pada Iklan Tempo Doeloe dan Implikasinya bagi Perkuliahan Bahasa Indonesia. Transformatika: Jurnal Bahasa, Sastra, dan Pengajarannya, 2(1), 58--67. https://doi.org/10.31002/transformatika.v2i1.553

Sumarsono. (2012). Sosiolinguistik. Pustaka Pelajar.

Undang-Undang Republik Indonesia pasal 36 Nomor 24 Tahun 2009

Zulaeha. (2010). Dialektologi: Dialek Geografi dan Sosial (2010 ed.). Graha Ilmu. 


\section{Lampiran 1}

\section{Daftar Nama Unit Usaha Milenial}

\begin{tabular}{|c|c|c|c|}
\hline No & Nama Unit Usaha & Tempat & Keterangan \\
\hline 1. & Warunk Mienie & $\begin{array}{l}\text { Jalan Raya Larangan Tokol, Kramat, } \\
\text { Panglegur, Kecamatan Pamekasan }\end{array}$ & Ejaan \\
\hline 2. & Mark Us & $\begin{array}{l}\text { Jalan Bhayangkara, Sekarputih, Laden, } \\
\text { Kecamatan Pamekasan }\end{array}$ & Serapan \\
\hline 3. & Go Kill Café & $\begin{array}{l}\text { Jalan Raya Kangean, No.151, Kangenan, } \\
\text { Kecamatan Pamekasan }\end{array}$ & Serapan \\
\hline 4. & Waroeng Cak Mamat & $\begin{array}{l}\text { Jalan Balaikambang No.20, RW 07, } \\
\text { Barurambat Kota }\end{array}$ & Ejaan \\
\hline 5. & $\begin{array}{l}\text { Mukerenz Coffe dan } \\
\text { Resto }\end{array}$ & Jalan Raya Sumenep No.278 & Serapan \\
\hline 6. & Café OTW & $\begin{array}{l}\text { Jalan, Jokotole No.157, Serkesen, Barurambat, } \\
\text { Kabupaten Pamekasan }\end{array}$ & Serapan \\
\hline 7. & $\begin{array}{l}\text { Daoen Bamboe Resto \& } \\
\text { Café }\end{array}$ & Jalan Sersan Mesrul II, No. 25 & Ejaan \\
\hline 8. & I'm Banana & Jalan Pintu Gerbang No.157 & Serapan \\
\hline 9. & D’ Lucky Café & Jalan Besar No. 1 & Serapan \\
\hline 10. & $\begin{array}{l}\text { Andayani Waroeng } \\
\text { Steak'n Djawa }\end{array}$ & Jalan Niaga No.51 & Ejaan \\
\hline 11. & N'dra with LB & RW III, Rong Tengah, Kec.Sampang & Serapan \\
\hline 12. & Bi Queen & $\begin{array}{l}\text { Jalan Raya Sumenep, Asemmanis, Buddagan } \\
\text { Pademawu, Kabupaten Pamekasan }\end{array}$ & Serapan \\
\hline 13. & K-One Café & Jalan Raya Tj.Pademawu, Muspada & Serapan \\
\hline 14. & K-Days coffe & Jalan Trunojoyo, Patemon, Kec.Pamekasan & Serapan \\
\hline 15. & PEWE Coffe \& Dining & Jalan Pintu Gerbang & $\begin{array}{l}\text { Serapan dan } \\
\text { Pemaknaan }\end{array}$ \\
\hline 16. & M2 Warkop & Jalan Talang Siring No.253 & Serapan \\
\hline 17. & Warkop CaffeIN & Jalan Raya Kangenan No.3a & Serapan \\
\hline 18. & MANK'S Café & $\begin{array}{l}\text { Asemanis Dua, Larangan Tokol, Kabupaten } \\
\text { Pamekasan }\end{array}$ & Serapan \\
\hline 19. & $\begin{array}{l}\text { Hedon Milkshake N } \\
\text { Thai Tea }\end{array}$ & $\begin{array}{l}\text { Barat, Ceguk, Tlanakan, Kabupaten } \\
\text { Pamekasan }\end{array}$ & Serapan \\
\hline 20. & Kedai Laperpool & Selatan Kampus UI Madura, Gladak, Battet & $\begin{array}{l}\text { Serapan dan } \\
\text { pemaknaan }\end{array}$ \\
\hline 21. & Djagongan Café & Jalan Gunung & Ejaan \\
\hline 22. & Mie Setan Kekkekek & $\begin{array}{l}\text { RW V, Rong Tengah Sampang, Kabupaten } \\
\text { Sambang }\end{array}$ & Pemaknaan \\
\hline 23. & Bakso Gong & $\begin{array}{l}\text { Serkeser, Buddagan, Padewamu, Kabupaten } \\
\text { Pamekasan }\end{array}$ & Pemaknaan \\
\hline 24. & $\begin{array}{l}\text { Bakso Beranak Mas } \\
\text { Dodo }\end{array}$ & $\begin{array}{l}\text { Jalan Jembatan Baru, Gladak Anyar, } \\
\text { Kec.Pamekasan }\end{array}$ & Pemaknaan \\
\hline 25. & Kedai Nun & $\begin{array}{l}\text { Jalan Daksinapati Raya No.4 Rawamangun, } \\
\text { Jakarta Timur }\end{array}$ & Serapan \\
\hline 26. & Loe Mien Toe & Jalan Tata Surya 2, Malang & Ejaan \\
\hline
\end{tabular}




\begin{tabular}{|l|l|l|l|}
\hline 27. & $\begin{array}{l}\text { TsunaMie Noodle } \\
\text { \&Café }\end{array}$ & $\begin{array}{l}\text { Jalan Melati, Lowokwaru, Kecamatan } \\
\text { Lowokwaru, Kota Malang }\end{array}$ & Ejaan \\
\hline 28. & $\begin{array}{l}\text { d' Toengkoe Cafe \& } \\
\text { Resto }\end{array}$ & $\begin{array}{l}\text { Gg.5 No.12, Mergosono, Kec. } \\
\text { Kedungkandang, Kota Malang, Jawa Timur }\end{array}$ & Ejaan \\
\hline 29. & Toeman Cafe and Eatery & $\begin{array}{l}\text { Jalan Joyo Tambaksari No.89, Merjosari, } \\
\text { Kecamatan Lowokwaru. }\end{array}$ & Ejaan \\
\hline 30. & Djoedjoegan & Jalan Kalasan No.15, Pacar Keling, Surabaya & Ejaan \\
\hline 31. & Dot Com Cafe & $\begin{array}{l}\text { Jalan Raya Ngagel Jaya, No.86, Pucang Sewu, } \\
\text { Surabaya }\end{array}$ & Serapan \\
\hline 32. & Shae Cafe and Eatery & Jalan Bawean No.3, Ngagel, Surabaya & Serapan \\
\hline 33. & d'riAll Cafe & Jalan Sukodami II, No.18, Manyar Sabrangan & $\begin{array}{l}\text { Serapan, } \\
\text { Pemaknaan }\end{array}$ \\
\hline 34. & W'ant Cafe & $\begin{array}{l}\text { Kecamatan Dukuh Pakis, Surabaya } \\
\text { Serapan }\end{array}$ \\
\hline 35. & Warunk Upnormal & Jalan Braga, No.78, Bandung & $\begin{array}{l}\text { Ejaan dan } \\
\text { Pemaknaan }\end{array}$ \\
\hline 36. & Tjarani Cafe Bandung & Jalan Bungur No.25 & Ejaan \\
\hline 37. & CO\&B Cafe & Jalan Kuningan Raya No.35 Bandung & Serapan \\
\hline
\end{tabular}

\section{Catatan}

Variasi unit usaha tersebut tersebar di ruang publik. Data di luar Madura diperoleh melalui Google Map (kecuali kedai Nun Rawamangun). 
